\title{
ALLELOPATHIC EFFECTS OF AQUEOUS EXTRACT OF LEAVES OF PARTHENIUM HYSTEROPHORUS L. ON SEED GERMINATION AND SEEDLING GROWTH OF SOME CULTIVATED AND WILD HERBACEOUS SPECIES
}

\author{
Seerjana Maharjan*, Bharat Babu Shrestha** and Pramod Kumar Jha** \\ *Royal Model Academy, Sorhakhutte, Kathmandu, Nepal. \\ **Central Department of Botany, Tribhuvan University, Kirtipur, Kathmandu, Nepal.
}

\begin{abstract}
Allelopathic effects of aqueous extract of leaves of Parthenium hysterophorus were studied on seed germination and seedling growth of three cereal crops (Oryza sativa L., Zea mays L. and Triticum aestivum L.), three cultivated crucifers (Raphanus sativus L., Brassica campestris L. and Brassica oleracea L.) and two wild species of family Asteraceae (Artemisia dubia Wall ex. Besser and Ageratina adenophora (Spreng) King and HE Robins). Seed germination of all crucifer species was completely inhibited at $>2 \%$ leaf extract of Parthenium hysterophorus but in other species, except maize, complete failure of seed germination was recorded only at $>6 \%$ in Triticum aestivum and Ageratina adenophora; at $10 \%$ in Oryza sativa and Artemisia dubia. Seed germination of Zea mays was not completely inhibited but it was low at high concentration of the extract. The extract had strong inhibitory effect to root elongation of seedling in cereals and to shoot elongation in crucifers and wild Asteraceae. Leaves of Parthenium hysterophorus may be a source of natural weedicide against Ageratina adenophora which will help to control invasive plants.
\end{abstract}

Key words: Alien invasive; Asteraceae; Cereal crops; Crucifers; Seedling biomass; Weedicide.

\section{INTRODUCTION}

A successful establishment of a weed in any ecosystem is attributed to several reasons, such as high growth rate, high reproductive potential, adaptive nature and above all interference by resource depletion and allelopathy (Kohil and Rani, 1994). Allelopathy concerns the effects of one plant on another due to chemicals released by them, or the breakdown products of their metabolites (Willis, 1994). Allelopathy has been suggested as a mechanism for the impressive success of invasive plants by establishing virtual monoculture and may contribute to the ability of particular exotic species to become dominants in invaded plant communities (Hierro, 2003; Kanchan and Jayachandra, 1979). Allelopathy is expected to be an important mechanism in the plant invasion process because the lack of co-evolved tolerance of resistant vegetation to new chemicals produced by the invader could allow these newly arrived species to dominant natural plant communities (Hierro, 2003). In fact, allelopathic interference is one of the important mechanisms for the successful establishment of invasive exotic weeds (Ridenour \& Callaway, 2001).

Parthenium hysterophorus, a native of tropical and subtropical America, is the most recent invader in Kathmandu valley. It has already threatened grassland ecosystems of Australia and India to a large extent (Stephen and Sowerby,
1996; Chippendale and Panetta 1994; Goyal and Brahma, 2001). This noxious weed was first reported from Nepal by Hara et al. (1982) but herbarium specimen was collected first in 1967 by Malla from Trishuli (Tiwari et al. 2005). Parthenium hysterophorus appears to be potentially most harmful to native flora, animals and human health. Although it has already invaded grasslands of most of the urban cities (e.g. Kathmandu, Pokhara, Narayangarh, etc) and near highways in tropical to subtropical region no effort has been made to control Parthenium hysterophorus, neither there is any study in Nepal to examine the effect of its invasion to native ecosystem. To explore allelopathic potential of Parthenium hysterophorus we examined effect of aqueous extract of leaves of this plant on seed germination and seedling growth of six cultivated crop species (three cereals and three crucifers) and two wild species of Asteraceae growing naturally together with Parthenium hysterophorus.

\section{MATERIALS AND METHODS}

\section{Species Characters}

Parthenium hysterophorus L. (Family: Asteraceae; common names: Bitter weed, false ragweed, fever few, Parthenium weed, Ragweed, white top, etc; vernacular names: Kanike ghans, Bethu ghans, or Padke phul) is an annual, erect and profusely branched herb. Height varies between $50-150 \mathrm{~cm}$,

Author for Correspondence: Pramod Kumar Jha, Central Department of Botany, Tribhuvan University, Kirtipur, Nepal.

E-mail: pkjha@ecos.wlink.com.np 
stem highly branched; leaf simple with profusely dissected leaflets; flower heads occur on a corymb, phyllaries 10 in 2 series, ovate, dull white, 3-4 mm in diameter; disc floret: numerous, dull white; stamen - 4, anther- exerted; ovary sterile; ray floret: found just opposite to inner phyllaries, only 5 ray florets per flower head, corolla obsolete, stamen-absent, stigma-parted, style short, ovary oval, dorsiventrally flattened. Fruit cypsela, each flower head bearing 5 cypsela, flat and triangular in shape with thin, white, spoon shaped appendages (Maharjan, 2006). A typical mature plant can produce from 15000 to 25000 seeds (Haseler, 1976; Joshi, 1991).

\section{Collection of Plant Materials}

Fresh leaves of Parthenium hysterophorus in its vegetative stage were collected from roadside fallow land of Kirtipur ( $27^{\circ} 40.948^{\prime} \mathrm{N}, 85^{\circ} 18.120^{\prime} \mathrm{E}$, alt. $1320 \mathrm{~m}$ asl) and air dried in shade for a week. The dried leaves were stored in plastic bags for one month at room temperature (average during day: $25^{\circ} \mathrm{C}$ ) before used for experiments.

\section{Experiments}

From preliminary screening it was found that leaf extract had the strongest allelopathic effect on seed germination; thus we selected leaves for detail experiments. Ten gram of air dried leaves of Parthenium hysterophorus was ground, mixed with $100 \mathrm{ml}$ distilled water and left for $24 \mathrm{~h}$ in dark at the room temperature (average during day: $25^{\circ} \mathrm{C}$ ) for extraction. Aqueous extract was obtained as filtrate of the mixture and final volume was adjusted to $100 \mathrm{ml}$; this gave $10 \%$ aqueous extract. The extract was considered as stock solution and a series of solution with different strengths (2, 4, 6 and 8\%) were prepared by dilution. Ten uniform and surface sterilized seeds (2\% sodium hypochlorite for $15 \mathrm{~min}$ ) of rice (Oryza sativa L. local var. khumal 4) were kept for germination in sterilized petri-dishes lined double with blotting paper and moistened with $10 \mathrm{~mL}$ of different concentrations of aqueous extracts (2 to 10\%). Each treatment had three replicas (total number of test seeds: $10 \times 3=30$ ). One treatment was run as control with distilled water only. The petri-dishes were maintained under laboratory conditions (room temperature $25^{\circ} \mathrm{C}$ at mid day, and diffused light during day) for one week. Equal volume of distilled water was added in the dishes when moisture content of the blotting paper declined. After one week, number of germinated seeds were counted and, the root and shoot length were measured. All root and shoot from each petridish were cut separately and oven dried at $70^{\circ} \mathrm{C}$ for $48 \mathrm{~h}$ to get dry biomass of root and shoot; total
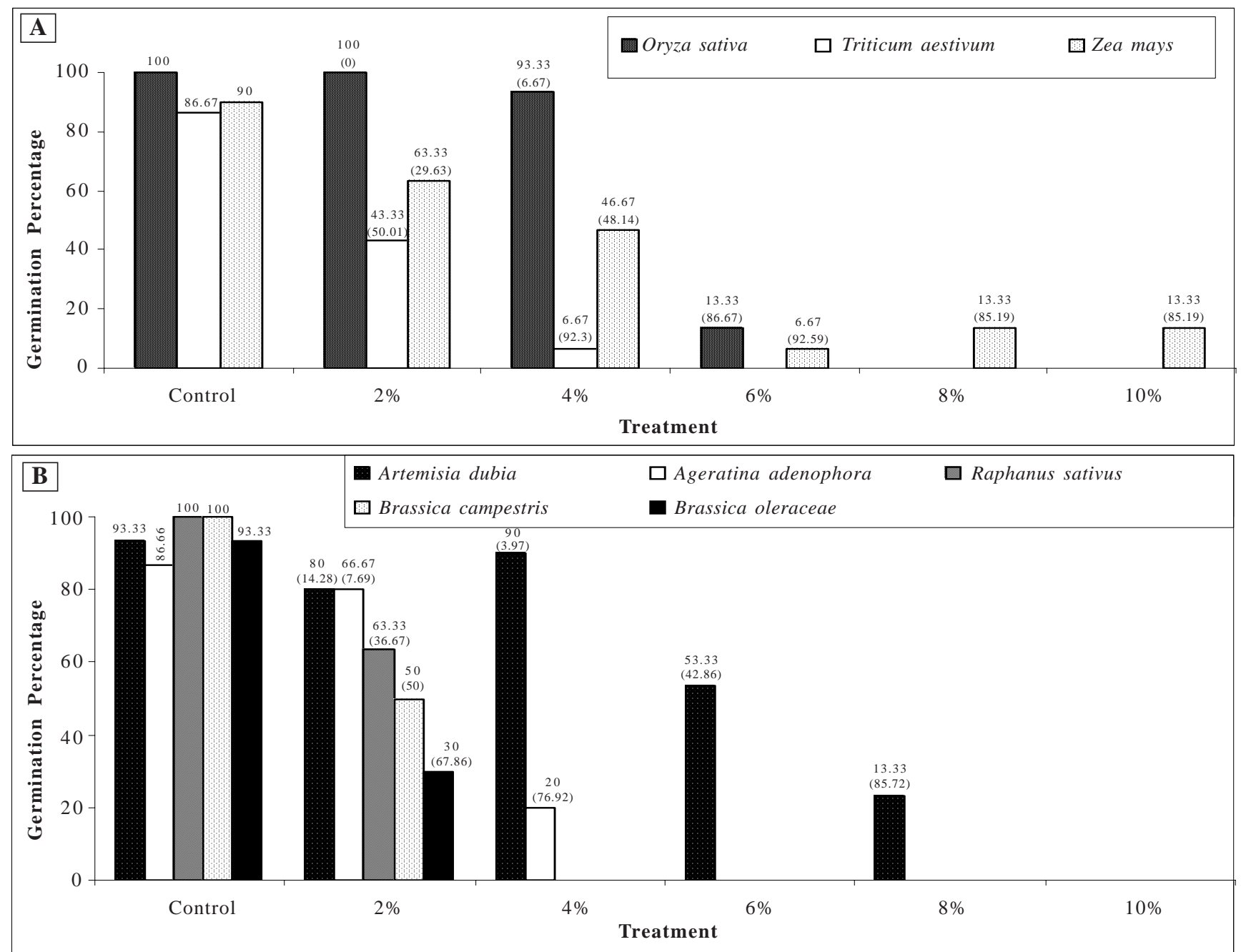

Figure 1: Seed germination percentage of studied monocot (A) and dicot (B) species under different treatments of leaf aqueous extracts of Parthenium hysterophorus. The figures in parentheses indicate percentage reduction in seed germination from control. 
Table 1: Analysis of Variance (ANOVA) in root length and shoot length of different plant species among different treatments of leaf aqueous extract of Parthenium hysterophorus. Degree of freedom (d.f.) for all treatments: 5

\begin{tabular}{|c|c|c|c|c|c|c|c|}
\hline Plant species & Parameters & $\mathbf{F}$ & Sig. & Plant species & Parameters & $\mathbf{F}$ & Sig. \\
\hline \multirow{2}{*}{ Oryza sativa } & root length & 174.285 & .000 & \multirow{2}{*}{ Brassica campestris } & root length & 40.014 & .000 \\
\hline & shoot length & 45.051 & .000 & & shoot length & 165.169 & .000 \\
\hline \multirow{2}{*}{ Triticum aestivum } & root length & 92.132 & .000 & \multirow{2}{*}{ Brassica oleracea } & root length & 10.594 & .000 \\
\hline & shoot length & 39.741 & .000 & & shoot length & 43.754 & .000 \\
\hline \multirow{2}{*}{ Zea mays } & root length & 16.887 & .000 & \multirow{2}{*}{ Artemisia dubia } & root length & 14.497 & .000 \\
\hline & shoot length & 9.250 & .000 & & shoot length & 28.942 & .000 \\
\hline \multirow{2}{*}{ Raphanus sativus } & root length & 32.942 & .000 & \multirow{2}{*}{ Ageratina adenophora } & root length & 15.962 & .000 \\
\hline & shoot length & 37.794 & .000 & & shoot length & 20.945 & .000 \\
\hline
\end{tabular}

seedling biomass of seedling was calculated as the sum of biomass of root and shoot.

Same procedure was followed to evaluate allelopathic effects of $P$. hysterophorus on seed germination and seedling growth of other two cereal crops: maize (Zea mays L. local var. Rampur Composite and wheat (Triticum aestivum L. local var. Godavari); three crucifers: radish (Raphanus sativus L. local var. Mino early), mustard (Brassica campestris L. local var. Khumal rato pat), and cauliflower (Brassica oleracea L. var. botrytis L. local var. Jyapu); and two wild Asteraceae Artemisia dubia Wall ex. Besser and Ageratina adenophora (Spreng) King and HE Robins.

\section{Statistical Analysis}

Significance of the difference in root and shoot length of seedlings under different treatments were tested and compared using Analysis of Variance (ANOVA) and Homogeneity test. Regression analysis between treatments vs. root and shoot length of seedlings among cereals, crucifers and wild Asteraceae were done by compiling all data of cereals, crucifers and wild Asteraceae. Change in germination percentage with concentration of aqueous extract was evaluated using regression analysis for the combined data of all test species. All statistical analyses were done using Statistical Package for Social Sciences (SPSS version 11.5, 2002).

\section{RESULTS}

\section{Germination}

Except in Zea mays, there was complete failure of seed germination of test species in 10\% aqueous extract. Even in $6 \%$ and $8 \%$ there were no germination of Triticum aestivum and Ageratina adenophora. The inhibition of germination was found strong in the crucifer species (Raphanus sativus, Brassica campestris and Brassica oleracea); there was no germination at $>2 \%$ concentration (Fig. 1B). At 2\% concentration, germination of Brassica oleracea was found to be reduced more as compared to control (67.86\%) followed by Triticum aestivum and Brassica campestris (50\%) (Fig. 1). At 4\% concentration, among germinating species (Oryza sativa, Triticum aestivum, Zea mays, Ageratina adenophora and Artemisia dubia), the Triticum aestivum showed maximum reduction in germination (92.3\%) over control. The regression analysis between germination percentage and concentration of extract showed that $65 \%$ of variation in germination of the test species could be explained by concentration of leaf extracts $\left(\mathrm{R}^{2}=0.65\right.$, Fig. 2$)$.

\section{Seedling Growth}

ANOVA showed significant difference $(\mathrm{p}<0.001)$ between treatments in root and shoot length of all test seedlings (Table 1). Among the cereal species there was highest reduction in the root and shoot length of Triticum aestivum (Table 2). The homogeneity test showed that root length of Oryza sativa at $2-6 \%$ was significantly different from that of control. The root length of Triticum aestivum at $4 \%$ and $2 \%$ were significantly different from that of control. Whereas in Zea mays, root length at $4-10 \%$ was different from that of control. Among crucifer species, the root length of Brassica campestris was highly reduced (92.79\%) at $2 \%$ concentration as compared to control. Among the wild Asteraceae the root length of Ageratina adenophora was reduced more (70.59\%) at $4 \%$ as compared to control. The root length of Ageratina adenophora at $2 \%$ and $4 \%$ and that of Artemisia dubia at 2$8 \%$ were significantly different from that of control in both the cases (Table 2).

The shoot length at 4-6\% were significantly different from that of control in Oryza sativa (Table 2). The root length of Triticum aestivum at $2 \%$ and $4 \%$ were significantly different from that of control whereas in Zea mays it was different from control only at $6-10 \%$. Among crucifer species there was highest reduction in shoot length of Brassica oleracea (80.2\%) at 2\% concentration (Table 2). Among Asteraceae the shoot length of Ageratina adenophora declined more

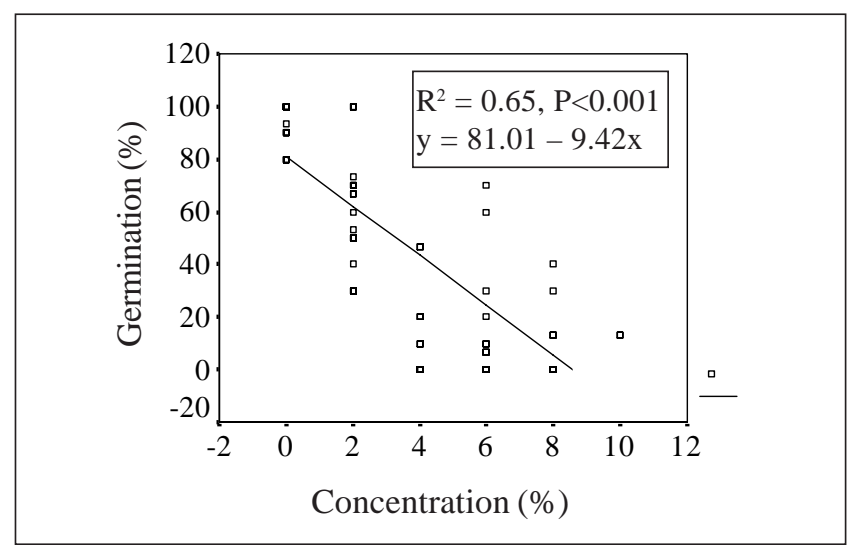

Figure 2: Regression analysis showing variation in seed germination of all test species with concentration of leaf aqueous extracts of Parthenium hysterophorus. 
(60.78\%) at $4 \%$ concentration as compared to control. The shoot length of Ageratina adenophora at 2\% and that of Artemisia dubia at 6\% and 8\% were significantly different from that of control in both the cases (Table 3).

Regression analysis between treatments vs. root and shoot length among cereals, crucifers and wild Asteraceae showed that the root length and shoot length of all species declined with increasing concentration of the extract $(p<0.001)$ (Fig. 3) but at higher concentration reduction was high for root length in the cereal, and for shoot length in crucifer and wild Asteraceae (Fig. 3). In these cases high reduction was indicated by higher slope of regression line.

Shoot and root biomass of seedlings of Oryza sativa, Artemisia dubia and Ageratina adenophora couldn't be measured because the mass was beyond the limit of our balance $(0.001 \mathrm{~g})$. Among the remaining species shoot and root biomass of Zea mays seedlings were the highest (Fig. 4).

\section{DIscussion}

From preliminary screening it was found that leaf extract had the strongest allelopathic effect on seed germination. Tefera (2002) also found that the inhibitory allelopathic impact of leaf extract was more powerful than of other vegetative parts.
Phytochemical analysis had already reported high accumulation of growth inhibitors in leaves of Parthenium hysterophorus (Kanchan 1975).

The study demonstrated that leaf aqueous extracts of Parthenium hysterophorus exhibited significant inhibitory effects on seed germination and seedling growth of all test species (three cereal crops, three crucifer vegetables, and two Asteraceae species (Figs. 1, 2, Table 2). Earlier works have also reported that foliar leachates of Parthenium hysterophorus reduced root and shoot elongation of Oryza sativa and wheat (Singh and Sangeeta 1991), maize and soyabeans (Bhatt et al. 1994) as well as some common Australian pasture grasses (Adkins and Sowerby 1996). This indicates the availability of the inhibitory chemicals in higher concentration in leaves than in stem and roots (Kanchan and Jayachandra 1980). The regression analysis between germination percentage and extract concentration showed that the germination of the test species were significantly $(\mathrm{p}<0.001)$ reduced with the increase in the concentration $\left(\mathrm{R}^{2}\right.$ $=0.65$, Fig. 2). Among the treatments, $8 \%$ and $10 \%$ aqueous extracts had the strongest inhibitory effect on germination (Fig. 1). Terera (2002) also reported that 10\% leaf aqueous extract of Parthenium hysterophorus resulted in complete failure of seed germination in Eragostis tef. Singh et al. (2005b)

Table 2: Effect of aqueous extract of Parthenium hysterophorus on root and shoot length of different plant species measured after one week. Different letters in superscript of the values in vertical rows indicate that the values are sgnificantly different (á $=0.05$ ).

\begin{tabular}{|c|c|c|c|c|c|c|c|c|}
\hline Treatment & $\begin{array}{l}\text { Oryza } \\
\text { sativa }\end{array}$ & $\begin{array}{l}\text { Triticum } \\
\text { aestivum }\end{array}$ & $\begin{array}{l}\text { Zea } \\
\text { mays }\end{array}$ & $\begin{array}{c}\text { Raphanus } \\
\text { sativus }\end{array}$ & $\begin{array}{c}\text { Brassica } \\
\text { campestris }\end{array}$ & $\begin{array}{c}\text { Brassica } \\
\text { oleraceae }\end{array}$ & $\begin{array}{c}\text { Ageratina } \\
\text { adenophora }\end{array}$ & $\begin{array}{c}\text { Artemisia } \\
\text { dubia }\end{array}$ \\
\hline & \multicolumn{8}{|c|}{ Root Length (cm.) } \\
\hline Control & $8.74^{\mathrm{c}}$ & $15.14^{c}$ & $18.54^{d}$ & 7.79 & 3.19 & 3.06 & $0.34^{\mathrm{b}}$ & $0.2821^{\mathrm{C}}$ \\
\hline $2 \%$ & $\begin{array}{c}2.23^{\mathrm{b}} \\
(74.48)\end{array}$ & $\begin{array}{c}7.38^{\mathrm{b}} \\
(51.27)\end{array}$ & $\begin{array}{l}12.82^{\mathrm{cd}} \\
(30.85)\end{array}$ & $\begin{array}{c}1.75 \\
(77.54)\end{array}$ & $\begin{array}{c}0.23 \\
(92.79)\end{array}$ & $\begin{array}{c}0.39 \\
(87.25)\end{array}$ & $\begin{array}{c}0.18^{\mathrm{a}} \\
(47.06)\end{array}$ & $\begin{array}{l}0.21^{\mathrm{b}} \\
(25)\end{array}$ \\
\hline $4 \%$ & $\begin{array}{c}0.38^{\mathrm{a}} \\
(95.65)\end{array}$ & $\begin{array}{c}0.55^{\mathrm{a}} \\
(96.37)\end{array}$ & $\begin{array}{l}10.73^{\mathrm{bc}} \\
(42.13)\end{array}$ & NG & NG & NG & $\begin{array}{c}0.1^{\mathrm{a}} \\
(70.59)\end{array}$ & $\begin{array}{l}0.29^{c} \\
+\end{array}$ \\
\hline $6 \%$ & $\begin{array}{c}0.08^{\mathrm{a}} \\
(99.08)\end{array}$ & NG & $\begin{array}{c}4.77^{\mathrm{ab}} \\
(74.27)\end{array}$ & NG & NG & NG & NG & $\begin{array}{c}0.11^{\mathrm{a}} \\
(60.71)\end{array}$ \\
\hline $8 \%$ & NG & NG & $\begin{array}{c}0.65^{\mathrm{a}} \\
(96.49)\end{array}$ & NG & NG & NG & NG & $\begin{array}{c}0.11^{\mathrm{a}} \\
(60.71)\end{array}$ \\
\hline \multirow[t]{2}{*}{$10 \%$} & NG & NG & $\begin{array}{c}0.18^{\mathrm{a}} \\
(99.03)\end{array}$ & NG & NG & NG & NG & NG \\
\hline & \multicolumn{8}{|c|}{ Shoot Length (cm.) } \\
\hline Control & $5.43^{c}$ & $9.74^{b}$ & $16.17^{\mathrm{d}}$ & 12.51 & 4.13 & 3.94 & $1.02^{\mathrm{c}}$ & $0.7^{\mathrm{b}}$ \\
\hline $2 \%$ & $\begin{array}{l}5.26^{\mathrm{c}} \\
(3.13)\end{array}$ & $\begin{array}{l}9.21^{\mathrm{b}} \\
(5.44)\end{array}$ & $\begin{array}{l}10.04^{\text {bcd }} \\
(37.91)\end{array}$ & $\begin{array}{c}2.49 \\
(80.1)\end{array}$ & $\begin{array}{c}1.23 \\
(70.22)\end{array}$ & $\begin{array}{c}0.78 \\
(80.2)\end{array}$ & $\begin{array}{c}0.76^{\mathrm{b}} \\
(25.49)\end{array}$ & $\begin{array}{l}0.77^{\mathrm{b}} \\
\quad+\end{array}$ \\
\hline $4 \%$ & $\begin{array}{c}2.66^{\mathrm{b}} \\
(51.01)\end{array}$ & $\begin{array}{c}3^{\mathrm{a}} \\
(69.2)\end{array}$ & $\begin{array}{c}10.8^{\text {cd }} \\
(33.21)\end{array}$ & NG & NG & NG & $\begin{array}{c}0.4^{\mathrm{c}} \\
(60.78)\end{array}$ & $\begin{array}{c}0.84^{\mathrm{b}} \\
+\end{array}$ \\
\hline $6 \%$ & $\begin{array}{c}0.2^{\mathrm{a}} \\
(96.32)\end{array}$ & NG & $\begin{array}{c}2.17^{\mathrm{a}} \\
(86.58)\end{array}$ & NG & NG & NG & NG & $\begin{array}{c}0.37^{\mathrm{a}} \\
(47.14)\end{array}$ \\
\hline $8 \%$ & NG & NG & $\begin{array}{l}4.53^{\mathrm{abc}} \\
(71.99)\end{array}$ & NG & NG & NG & NG & $\begin{array}{c}0.24^{\mathrm{a}} \\
(65.71)\end{array}$ \\
\hline $10 \%$ & NG & NG & $\begin{array}{c}3.57^{\mathrm{ab}} \\
(77.99)\end{array}$ & NG & NG & NG & NG & NG \\
\hline
\end{tabular}

The data in parenthesis indicate \% reduction over control and + indicates stimulation.

NG= No Germination. 


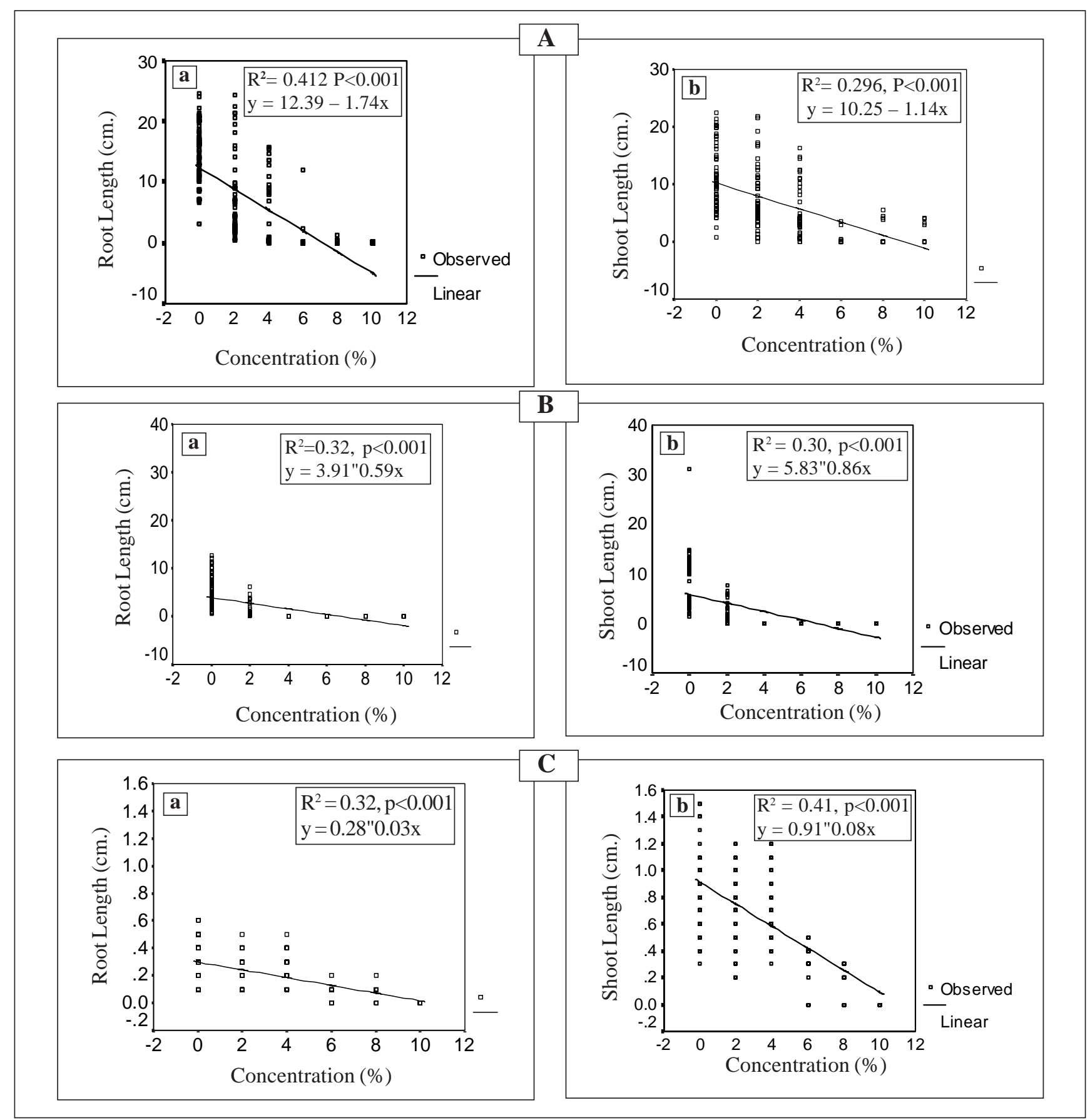

Figure 3: Relationship between concentration of leaf aqueous extract of Parthenium hysterophorus and root (a) and shoot (b) length of (A) cereal species, (B) crucifer species and (C) wild Asteraceae.

also found a strong positive correlation between extract concentration of residues of Parthenium hysterophorus and reduction in seedling length of Brassica species. The 10\% leaf aqueous extract completely inhibited seed germination of Oryza sativa, Triticum aestivum, Ageratina adenophora, Artemisia dubia, Raphanus sativus, Brassica campestris and Brassica oleracea. This could occur only when some allelochemicals present in the leaf extract prevented growth of embryo, or caused the death. The extract of Parthenium hysterophorus induced a variety of chromosomal aberrations in dividing cells, which increased significantly with increasing concentrations and durations of exposure (Rajendiran 2005).

At 4\% concentration, among germinating species (Oryza sativa, Triticum aestivum, Zea mays, Ageratina adenophora and Artemisia dubia), the Triticum aestivum showed maximum reduction in germination (92.3\%) over control. A reduction in seed germination of wheat by $80-90 \%$ due to soaking of its seeds in stem aqueous extract of Parthenium hysterophorus for 20 and 40 h has been reported by Rajan (1973). Srivastava et al. (1985) revealed that aqueous extracts of leaves and inflorescences inhibited the germination and seedling growth of barley, wheat and peas. In present study there were strong inhibition in seed germination of the crucifer species (Raphanus sativus, Brassica campestris and Brassica oleracea) even in $2 \%$ concentration and complete inhibition above this (Fig. 1B). The seeds of these crucifers appeared 
to be the most sensitive among the test species to inhibitory effect of leaf aqueous extract of Parthenium hysterophorus. Since crucifers are important vegetables and cash crops of Kathmandu valley, invasion by Parthenium hysterophorus into farmland may have adverse effect on local agroeconomy.

From the homogeneity test it was found that the shoot length of all the test species (except Ageratina adenophora) at 2\% concentration was not significantly different from that of control; whereas at the same concentration (2\%) root length (except in Zea mays) was significantly different from the control (Table 2). It indicated that root elongation was affected more than of the shoot. Similar effect of leaf aqueous extract of Parthenium hysterophorus was reported by Tefera (2002) on Eragostis tef and Rajan (1973) on wheat. The strong inhibitory effects that Parthenium hysterophorus had on root elongation might be due to direct contact of root with the extract and subsequently with inhibitory chemicals as described in early works with various crops and weeds (Bhowmik and Doll 1984, Quasem 1995). At higher concentration reduction in length was higher for root than shoot in cereals (higher slope of regression line for RL, Fig. 3A); for crucifers and wild Asteraceae reduction in shoot length was higher than reduction in root length at higher concentrations (Fig. 3B, C) Thus sensitivity to allelochemicals and extent of inhibition varied with species and organs of the test species.

The inhibitory effect of Parthenium hysterophorus on seed germination and seedling growth of different plant species is due

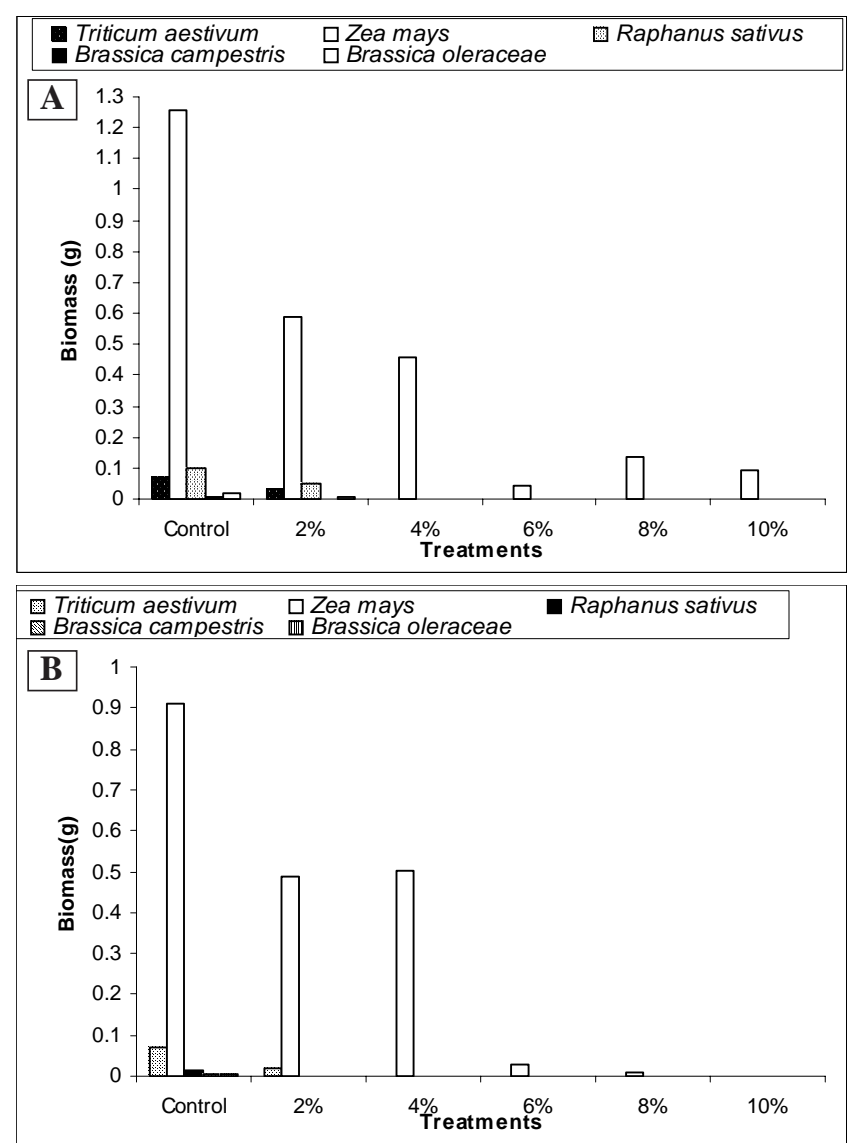

Figure 4: Total oven dried biomass of shoot (A) and root (B) seedlings of test species in each petri dish (10 seeds) at different concentrations. Each value is the mean of three replicas. to presence of growth inhibitors (allelochemicals) in the extracts. Rajan (1973) and Kanchan (1975) were the first to report the presence of plant growth inhibitors in Parthenium hysterophorus. This plant releases a number of water soluble allelochemicals such as phenolic acid and sesquiterpene lactones, particularly parthenin (Kanchan 1975, Swaminathan et al., 1990, Stephen and Sowerby 1996). Phenolics found in leaves also have inhibitory effects on growth of nitrogen fixing and nitrifying bacteria (Kanchan and Jayachandra 1981). According to Rice (1984) phenolics are the most common and widely distributed water soluble allelochemicals. The escape of these chemicals into the environment occurs through various mechanisms such as leachation, volatilization and microbial decay of dead and fallen parts, as well as root exudation (Rice 1984). These chemicals were reported to have had allelopathic potential on various agronomic crops and weeds (Stephen and Sowerby, 1996; Mersie and Singh, 1987) and vegetable crops (Mersie and Singh, 1988). Patil and Hedge (1988) isolated parthenin in pure form from the leaves of Parthenium hysterophorus and demonstrated that this compound significantly decreased germination of wheat seeds and adversely affected seedling growth.

According to Kanchan and Jayachandra (1979) and Pandey (1994), Parthenium hysterophorus is one of the best known plant invaders in the world linking allelopathy to exotic invasion. The unique allelopathic effects of some exotic species on naïve, ‘inexperienced' communities (Callaway and Aschehoug, 2000) also contribute to invasive success. Allelopathy is expected to be an important mechanism in the plant invasion process. Lack of co-evolved tolerance of resident vegetation to new chemicals produced by the invader could allow these newly arrived species to dominate natural plant communities (Hierro and Callaway 2003). Parthenium hysterophorus, because of its invasive capacity and allelopathic properties, has the potential to disrupt natural ecosystems (Evans 1997). It has been reported as causing a total habitat change in native Australian grasslands, open woodlands, riverbanks and floodplains (McFadyen 1992, Chippendale and Panetta 1994).

According to Tiwari et al. (2005) Parthenium hysterophorus has not been used for any purpose in Nepal. Therefore this plant may become a high risk posed invasive species in near future. Present results showed that concentrated aqueous extract of leaves of Parthenium hysterophorus inhibited seed germination and seedling growth of other weeds such as Ageratina adenophora and Artemisia dubia, former being another invasive plant of the region. This result is also supported by similar previous reports of Batish et al. (1997, 2002). They reported germination inhibition of Amaranthus viridis, Chenopodium murale and Ageratum conyzoides by Parthenium hysterophorus. Thus, this plant could be exploited as a source of natural herbicides by maximizing its use for future weed management programmes.

\section{CONCLUSIONS}

The crucufer species (Raphanus sativus, Brassica campestris and Brassica oleracea) were more sensitive to inhibitory 
effects of leaf aqueous extract of Parthenium hysterophorus. Germination was completely inhibited at $>2 \%$ concentration in crucifer species. Except in maize, complete failure in seed germination of all test species were recorded at $10 \%$ extract. There was no seed germination of Triticum aestivum and Ageratina adenophora even at 6\% and 8\%. The extract had strong inhibitory effect to root elongation of seedlings in cereals and to shoot elongation in crucifers and wild Asteraceae. Thus, sensitivity to allelochemicals and extent of inhibition varied with species and organs of the test species. Allelopathic effect of Parthenium hysterophorus may be an important mechanism involved in invasive success of this plant. Allelochemicals of this plant can be exploited as a source of natural weedicide to control other invasive species.

\section{ACKNOWLEDGEMENTS}

The helps of Mrs. Sajag Adhikari during laboratory work is thankfully acknowledged.

\section{REFERENCES}

Adkins, S.W. \& Sowerby, M.S. 1996. Allelopathic potential of the weed Parthenium hysterophorus L. in Australia. Plant Protection Quarterly. 11: 20-23.

Batish, D.R., Kohil, R.K., Singh, H.P. \& Saxena, D.B. 1997. Studies on herbicidal activity of parthenin, a constituent of Parthenium hysterophorus towards billgoat weed (Ageratum conyzoides). Current Science. 73: 369-371.

Batish, D.R., Singh, H.P., Saxena, D.B. \& Kohil, R.K. 2002. Weed suppressing ability of parthenin - A sesquiterpene lactone from Parthenium hysterophorus. New Zealand Plant Protection. 55: 218-221.

Bhatt, B.P., Chauhan, D.S. \& Todaria, N.P. 1994. Effect of weed leachates on germination and radicle extension of some food crops. Indian Journal of Plant Physiology. 37: 177-179.

Bhowmik, P.C. \& Doll, J.D. 1984. Allelopathic effects of annual weed residues on growth and nutrient uptake of corn and soybeans. Agronomic Journal. 76: 383-388.

Callaway, R.M. \& Aschehoug, E.T. 2000. Invasive plants versus their new and old neighbors: a mechanism for exotic invasion. Science. 290: 521-523.

Chippendale, J.F. \& Panetta, F.D. 1994. The cost of Parthenium weed to the Queensland cattle industry. Plant Protection Quarterly. 9: 73-76.

Evans, H.C. 1997. Parthenium hysterophorus: A review of its weed status and the possibilities for biological control. Biocontrol: News and Information. 18(3): 89-98.

Goyal, C.P. \& Brahma, B.C. 2001. A ray of hope against Parthenium in Rajaji National Park. Indian Forester. 127(4): 409-414.

Haseler, W.H. 1976. Parthenium hysterophorus L. in Australia. Pest Articles \& News Summaries (PANS). 22: 515-517.

Hierro, J.L. \& Callaway, R.M. 2003. Allelopathy and exotic plant invasion. Plant and Soil. 256: 29-39.

Joshi, S. 1991. Interference effects of Cassia uniflora Mill. On Parthenium hysterophorus L. Plant and Soil. 132: 215-223.

Kanchan, S.D. 1975. Growth inhibitors from Parthenium hysterophorus L. Current Science. 44: 358-359.

Kanchan, S.D. \& Jayachandra. 1979. Allelopathic effects of Parthenium hysterophorus L. I. Exudation of inhibitors through roots. Plant and Soil. 53: 27-35.

Kanchan, S.D. \& Jayachandra. 1980. Allelopathic effects of Parthenium hysterophorus L. IV. Identification of inhibitors. Plant and Soil. 55: 67-75.
Kanchan, S.D. \& Jayachandra. 1981. Effects of Parthenium hysterophorus on nitrogen-fixing and nitrifying bacteria. Canadian Journal of Botany. 59: 199-202.

Kohil, K.K. \& Rani, D. 1994. Parthenium hysterophorus--a review. Research Bulletin (Sci.) Panjab University. 44: 105-149.

Maharjan, S. 2006. Phenology, leaf attributes and allelopathic potential of Parthenium hysterophorus L., a highly allergic invasive weed in Kathmandu valley, M. Sc Thesis, Central Department of Botany, Tribhuvan University.

McFadyen, R.E. 1992. Biological control against Parthenium Weed in Australia. Crop Protection. 11: 400-407.

Mersie, W. \& Singh, M. 1987. Allelopathic effects of Parthenium hysterophorus extract and residue on some agronomic crops and weeds. Journal of Chemical Ecology. 13: 1739-1747.

Mersie, W. \& Singh, M. 1988. Effects of phenolic acids and rageweed Parthenium hysterophorus L. extracts on tomato (Lycopersicum esculentum) growth and nutrient and chlorophyll content. Weed Science. 36: 278-281.

Pandey, D.K. 1994. Inhibition of salvinia (Salvinia molesta Mitchell) by parthenium (Parthenium hysterophorus L.). II. Relative effect of flower, leaf, stem, and root residue on salvinia and paddy. Journal of Chemical Ecology. 20: 3123-3131.

Patil, T.M. \& Hedge, B.A. 1988. Isolation and purification of sesquiterpene lactone from the leaves of Parthenium hysterophorus L. - its allelopathic and cytotoxic effets. Current Science. 42: 1178-1181.

Quasem, J.R. 1995. The allelopathic effect of three Amaranthus spp. (Pigweeds) on wheat (Triticum durum). Weed Research. 35: 41-49.

Rajan, L. 1973. Growth inhibitors from Parthenium hysterophorus L. Current Science. 42(20): 729-730.

Rajendiran, K. 2005. Mitodepressive effects of aqueous extracts of Parthenium hysterophorus L. on Vigna radiata (L) Wilczek. Geobios. 32(4): 237-240.

Rice, E.L. 1984. Allelopathy. $2^{\text {nd }}$ edition. Academic Press, Inc, Florida (USA).

Ridenour, W.M. \& Callaway, R.M. 2001. The relative importance of allelopathy in interference: the effects of invasive weed on native bunchgrass. Oecologica. 126: 444-450

Singh, H.P., Batish D.R., Pandher J.K. \& Kohil, R.K. 2005. Phytotoxic effects of Parthenium hysterophorus residues on three Brassica species. Weed Biology and Management. 5(3): 105-109.

Singh, S.P. \& Sangeeta. 1991. Allelopathic potential of Parthenium hysterophorus L. Journal of Agronomy and Crop Science. 167: 201-206.

Srivastava, J.N., Shukla, J.P. \& Srivastava, R.C. 1985. Effect of Parthenium hysterophorus L. extract on the seed germination and seedling growth of barley, pea and wheat. Acta Botanica Indica. 13: 194-197.

Stephen, W.A. \& Sowerby, M.S. 1996. Allelopathic potential of the weed, Parthenium hysterophorus L. in Australia. Plant Protection Quarterly. 11: 20-23.

Swaminathan, C., Rai, R.S.V. \& Sureshi, K.K. 1990. Allelopathic effects of Parthenium hysterophorus L. on germination and seedling growth of a few multipurpose trees and arable crops. The International Tree Crops Journal. 6: 143-150.

Tefera, T. 2002. Allelopathic effects of Parthenium hysterophorus extracts on seed germination and seedling growth of Eragrostis tef (Zucc.) Trotter, Journal of Agronomy and Crop Science. 188(5): 306-310.

Tiwari, S., Adhikari, B., Siwakoti, M. \& Subedi, K. 2005. An Inventory and Assessment of Invasive Alien Plant Species of Nepal, IUCNThe World Conservation Union, Nepal, Pp.40-41.

Willis, R.J. 1994. Terminology and trends in allelopathy. Allelopathy Journal. 1(1): 6-28. 